\title{
Thyroid Function and Deiodinase Activities in Rats with Marginal Iodine Deficiency
}

\author{
Karin P. L. T. M. K. Janssen,' DaAy van der Heide,", \\ Theo J. VISSER, ${ }^{2}$ Ellen Kaptein, ${ }^{2}$ and ANton C. Beynen ${ }^{3}$ \\ Department of Human and Animal Physiology, Agricultural University, \\ Haarweg 10, 6709 PJ, Wageningen, The Netherlands; Department of \\ Intemal Medicine III, Erasmus University Medical School, Rotterdam; \\ ${ }^{3}$ Department of Large Animal Medicine and Nutrition, Faculty of \\ Veterinary Medicine, State University, Utrecht, The Netherlands
}

Received April 2, 1993; Revised June 30, 1993; Accepted July 18, 1993

\begin{abstract}
The hypothesis tested was whether marginal iodine deficiency for a period of $6 \mathrm{wk}$ affects iodothyronine deiodinase activities in liver and brain of rats. Male rats were fed purified diets either deficient or sufficient in iodine; the diets were fed on a restricted basis $160 \%$ of ad libitum intake). Body weight gain of the two groups was comparable. lodine deficiency was evidenced by increased thyroid weight $(26 \%)$, reduced urinary iodine excretion (80\%), and reduced plasma $\mathrm{T}_{4}$ concentrations (22\%). Activities of liver type I and brain type III deiodinase were unchanged, but the activity of type II deiodinase in brain was increased $(28 \%)$ in the iodine-deficient rats. Food restriction per se significantly lowered $\mathrm{T}_{3}(30 \%)$ and $\mathrm{T}_{4}(22 \%)$ concentrations in plasma and decreased type III deiodinase activity in brain $(30 \%)$. These results indicate that in marginal iodine deficiency the activities of hepatic type I deiodinase and brain type III deiodinase are unchanged, whereas that of brain type II deiodinase is increased.
\end{abstract}

Index Entries: Rats; iodine deficiency; food restriction; thyroid; deiodination; liver; brain.

*Author to whom all correspondence and reprint requests should be addressed. 


\begin{abstract}
Abbreviations: DTT $=$ dithiotreithol; Hepes $=N$-[2-hydroxyethyl]piperazine- $N^{\prime}$-[2-ethanesulfonic acid]; PTU $=$ propylthiouracil; $I=$ iodine; $r T_{3}=$ reverse $T_{3}=3,3^{\prime}, 5^{\prime}$-triiodothyronine; $3,3^{\prime}-T_{2}=$ 3,3'-diiodothyronine; $T_{3}=3,3^{\prime}, 5$-triiodothyronine; $T_{4}=3,3^{\prime}, 5,5^{\prime}$ tetra-iodothyronine; $\mathrm{TSH}=$ thyroid stimulating hormone; $I R D=$ inner ring deiodination; $O R D=$ outer ring deiodination.
\end{abstract}

\title{
INTRODUCTION
}

Cretinism and goiter are often caused by iodine deficiency (1-3). lodine deficiency is associated with slightly elevated TSH, decreased $T_{4}$, and normal or slightly elevated $\mathrm{T}_{3}$ levels in plasma (4). Hypothyroidism is characterized by high TSH, low $\mathrm{T}_{4}$, and low $\mathrm{T}_{3}$ levels in plasma $(5,6)$.

In rats with hypothyroidism there is a marked decrease in type I iodothyronine deiodinase activity in liver $(7,8)$. A decrease in type III deiodination has also been found in brains of hypothyroid rats $(9,10)$. However, the activity of brain type II deiodinase is enhanced in hypothyroidism $(8-10)$.

The type I enzyme, mainly present in liver, kidney, and thyroid, catalyzes the deiodination of the outer and/or inner ring of different iodothyronines and is very important for the production of plasma $T_{3}$; it is most efficient in outer ring deiodination (ORD) of $\mathrm{rT}_{3}$. Type Il deiodinase only catalyzes ORD of $T_{4}$ to $T_{3}$ and $\mathrm{rT}_{3}$ to $3,3^{\prime}-\mathrm{T}_{2}$ and is important for the local production of $T_{3}$ in tissues such as brain. Type III deiodinase inactivates $T_{4}$ and $T_{3}$ by inner ring deiodination (IRD) and probably is important for the clearance of plasma $T_{3}(7)$.

The abovementioned studies with rats with severe hypothyroidism may not be relevant for the situation in humans in areas where moderately reduced intake is a problem. Therefore, we have induced in rats a marginal iodine deficiency that is not associated with growth retardation or other clinical signs. Using this animal model we determined the activities of type I deiodinase in liver homogenates and those of type II and III deiodinases in brain homogenates.

\section{MATERIALS AND METHODS}

The experimental protocol was approved and its execution supervised by the animal welfare officer of the Wageningen Agricultural University.

\section{Animals and Housing}

Male, 30-d-old Wistar rats (Cpb/Hsd; Harlan Inc, Zeist, The Netherlands) were used. During the pre-experimental period of $2 \mathrm{wk}$ (d-14-0), the rats were housed in groups of six animals in stainless-steel cages $(60$ $\times 42 \times 19 \mathrm{~cm}$ ) with wire mesh bases. During the experimental period of 
$6 \mathrm{wk}(\mathrm{d} 0-42)$ they were kept individually in metabolic cages $\left(314 \mathrm{~cm}^{2} \times\right.$ $15 \mathrm{~cm})$. The cages were placed in a room with controlled temperature $\left(20-22^{\circ} \mathrm{C}\right)$, relative humidity $(45-65 \%)$, and a 12 -h light-dark cycle (lights on: $7 \mathrm{AM}$ to $7 \mathrm{PM}$ ).

\section{Diets and Feeding}

The diets were in powdered form and stored at $4^{\circ} \mathrm{C}$ until feeding. During the pre-experimental period, all rats were fed a purified control diet and twice-distilled water ad libitum. The control diet was iodinesufficient $(1.2 \mu \mathrm{mol}$ added iodine $/ \mathrm{kg}$ ) and its composition was as follows: ovalbumin, $151 \mathrm{~g}$; corn oil, $25 \mathrm{~g}$; coconut fat, $25 \mathrm{~g}$; glucose, $709.4 \mathrm{~g}$; cellulose, $30 \mathrm{~g} ; \mathrm{CaCO}_{3}, 12.4 \mathrm{~g} ; \mathrm{NaH}_{2} \mathrm{PO}_{4} \cdot 2 \mathrm{H}_{2} \mathrm{O}, 15.1 \mathrm{~g} ; \mathrm{MgCO}_{3}, 1.4 \mathrm{~g}$; $\mathrm{KCl}, 1.0 \mathrm{~g}$; $\mathrm{KHCO}_{3}, 7.7 \mathrm{~g}$; $\mathrm{KIO}_{3}, 0.25 \mathrm{mg}$; iodine-free mineral premix, 10 $\mathrm{g}$; vitamin premix, $12 \mathrm{~g}$. The mineral premix consisted of $(\mathrm{mg}): \mathrm{MnO}_{2}, 79$; $\mathrm{NaF}, 2 ; \mathrm{NH}_{4} \mathrm{VO}_{3}, 0.2 ; \mathrm{FeSO}_{4} \cdot 7 \mathrm{H}_{2} \mathrm{O}, 174 ; \mathrm{NiSO}_{4} \cdot 6 \mathrm{H}_{2} \mathrm{O}, 13 ; \mathrm{ZnSO}_{4} \cdot \mathrm{H}_{2} \mathrm{O}, 33$; $\mathrm{CuSO}_{4} \cdot 5 \mathrm{H}_{2} \mathrm{O}, 15.7 ; \mathrm{SnCl}_{2} \cdot 2 \mathrm{H}_{2} \mathrm{O}, 1.9 ; \mathrm{Na}_{2} \mathrm{SeO}_{3} \cdot 5 \mathrm{H}_{2} \mathrm{O}, 0.3 ; \mathrm{CrCl}_{3} \cdot 6 \mathrm{H}_{2} \mathrm{O}, 1.5$; corn meal, 9679.4. The vitamin premix consisted of $(\mathrm{mg})$ : thiamin, 4; riboflavin, 3; pyridoxine, 6 ; niacinamide, 20; D,1-calcium pantothenate, 17.8; folic acid, 1; biotin, 2; cyanocobalamine, 50; choline chloride, 2000; $D, L-\alpha-$ tocopheryl acetate, 60 ; menadione, 0.05 ; retinyl acetate and retinyl palmitate, 8 (1200 retinol equivalents); cholecalciferol, 0.025; corn meal, 9828.125.

At the end of the pre-experimental period $(\mathrm{d} 0)$, the rats were divided into three groups, which were stratified for body weight. One group of 12 rats and one group of 6 rats remained on the control diet. The other group of 12 rats received an iodine-deficient diet. To prepare the iodine-deficient diet, $\mathrm{KIO}_{3}$ was omitted from the control diet. The group of 6 rats was fed ad libitum. The other two groups received $60 \%$ of ad libitum intake; with this feeding regimen any difference in feed intake and growth rate between these groups would be precluded. Food was administered daily. Twice distilled water was freely available.

\section{Experimental Procedures}

Body weight was measured once a week. Food intake was measured daily. During the last $3 \mathrm{~d}$ of the experiment ( $\mathrm{d} 39-42)$ urine was collected quantitatively from each rat and stored at $-20^{\circ} \mathrm{C}$ until analysis. At the end of the experiment (d 42), the rats were anesthetized with diethyl ether and blood samples were collected in heparinized tubes by aorta puncture. The anesthetized rats were killed subsequently by $\mathrm{CO}_{2}$ inhalation. Organs were removed and weights determined immediately. Plasma was stored at $-20^{\circ} \mathrm{C}$ until analysis. Brains and livers were collected in liquid nitrogen and stored at $-80^{\circ} \mathrm{C}$ until analysis.

Urinary iodine and creatinine were determined as described by Kolthoff and Sandell (11) and by Folin (12), respectively. Plasma $T_{3}$ and $\mathrm{T}_{4}$ were analyzed by radioimmunoassays without prior extraction accord- 
ing to the method of Larsen (13), with minor modifications as described by Van Hardeveld and Kassenaar (14).

To prepare liver homogenates, a portion of the liver was weighed and homogenized in 10 volumes of ice-cold buffer A (10 $\mathrm{mM}$ Hepes, $0.25 \mathrm{M}$ sucrose and $10 \mathrm{mM}$ DTT, $\mathrm{pH} 7$ ). Brains (cerebral cortex, striatum, and midbrain) were homogenized in 5 vol of ice-cold buffer $A$. Homogenates were stored at $-70^{\circ} \mathrm{C}$ until analysis. Protein content of tissue homogenates were measured with the Bio-Rad protein assay (Pierce Europe, Oud Beijerland, The Netherlands) using bovine serum albumin as standard.

All deiodinase assays were performed in the presence of DTT by analysis of radioiodide production from ${ }^{125}$ I-labeled substrates, similarly to the method of Mol et al. (15). All deiodinase reactions were stopped by adding $100 \mu \mathrm{L}$ pooled human serum and $500 \mu \mathrm{L}$ ice-cold $10 \%$ TCA. Released ${ }^{125} \mathrm{I}^{-}$was separated from protein-bound iodothyronines by centrifugation. The data were corrected for nonenzymatic deiodination as determined in the absence of tissue homogenate. For calculation of deiodinase activities, random labeling of $3^{\prime}$ and $5^{\prime}$ positions of $\left.{ }^{125} \mathrm{I}\right] \mathrm{rT}{ }_{3}$ and $\left[{ }^{125} I\right] \mathrm{T}_{4}$ and of the 3 and 5 positions of $\left[{ }^{125} \mathrm{I}\right] \mathrm{T}_{3}$ was taken into account.

Hepatic type I deiodinase activity was determined by incubation of the appropriate amount of homogenate protein (final concentration 0.05 $\mathrm{mg} / \mathrm{mL}$ ) for $20 \mathrm{~min}$ at $37^{\circ} \mathrm{C}$ with $75 \mathrm{nCi}\left[3^{\prime}, 5^{\prime}-{ }^{125} \mathrm{I}\right] \mathrm{rT}_{3}$ and $1 \mu \mathrm{M} \mathrm{rT}_{3}$ in the presence of $10 \mathrm{mM}$ DTT in buffer $B$ (final concentrations: $0.1 \mathrm{M}$ sodiumphosphate, $2 \mathrm{mM}$ EDTA, $\mathrm{pH}$ 7.2; final volume: $200 \mu \mathrm{L}$ ).

Type II deiodinase activity was determined by incubation with 0.5 $\mathrm{nM}\left[3^{\prime}, 5^{\prime}-{ }^{125} \mathrm{I}\right] \mathrm{T}_{4}$ for $2 \mathrm{~h}$ at $37^{\circ} \mathrm{C}$ with brain homogenate (4 times diluted) in the presence of $1 \mu M T_{3}, 1 \mathrm{mM}$ PTU, and $25 \mathrm{mM}$ DTT in buffer B. PTU and $T_{3}$ were added to prevent possible interference by type $I$ and type III deiodinase. This was verified by HPLC analysis of parallel incubations $(n=12)$. Therefore the deiodinase reaction was stopped by adding 200 $\mu \mathrm{L}$ methanol to the incubation mixture. Iodothyronine metabolites were analyzed using HPLC (16). Furthermore, the correlation coefficient between $\left[{ }^{125} \mathrm{ITT}_{3}\right.$ production measured with $\mathrm{HPLC}$ and ${ }^{125} \mathrm{I}^{-}$production measured according to Mol et al. (15) was $0.9067(p=0.001)$.

Type III deiodinase activity in brain homogenates was determined by incubating $5 \mathrm{nM}\left[3,5-{ }^{125} I\right] \mathrm{T}_{3}$ (courtesy of $\mathrm{H}$. Rokos, Henning, Berlin, FRG) for $20 \mathrm{~min}$ at $37^{\circ} \mathrm{C}$ with diluted brain homogenate (final protein concentration $0.5 \mathrm{mg} / \mathrm{mL}$ ) in the presence of $1 \mu \mathrm{M} \mathrm{rT}, 0.1 \mathrm{mM}$ PTU and $50 \mathrm{mM}$ D'TT in $200 \mu \mathrm{L}$ buffer B. PTU and $\mathrm{rT}_{3}$ were added to block possible type I deiodination of the labeled $T_{3}$.

\section{Statistics}

Data were analyzed using the Statistical Package for Social Sciences (SPSS) (17). The level of significance was preset at $p<0.05$. Data were checked for normality. For normally distributed data, group means were 
compared using a two-tailed, unpaired Student's $t$-test. To take into account the increasing risk of a type I error caused by multiple comparisons, Bonferroni's adaptation of the $p$ value was applied, leading to a significance level of $p<0.025$. Mann-Whitney $U$ test was used to evaluate differences between group means of not normally distributed data (18).

\section{RESULTS}

\section{Body Weight and Organ Weights}

Initial ( $\mathrm{d} 0$ ) body weight of the rats was $138.1 \pm 11.8 \mathrm{~g}$ (mean $\pm \mathrm{SD}$, $n=30$ ). Average feed intake during the experiment by the group fed ad libitum was $21.8 \pm 1.6 \mathrm{~g} / \mathrm{d}$ (mean $\pm \mathrm{SD}, n=6$ ). Growth rates, final $(\mathrm{d} 42)$ body and organ weights of the experimental groups are shown in Table 1. Restricting feed intake to $60 \%$ of ad libitum intake reduced body weight gain by about $57 \%$ (Table 1). The rats fed the restricted amount of the control diet aiso had lower absolute organ weights. However, when expressed relative to body weight, the rats fed on a restricted basis had higher brain and pituitary weights, but lower liver weights. This can be explained by a lower degree of adiposity in the animals fed the restricted amount of feed. Restricted feeding of the iodine-deficient diet did not affect body weight, when compared with restricted feeding of the control diet (Table 1).

\section{Iodine Status}

Iodine deficiency significantly increased mean thyroid weight by $26 \%$ (Table 2). Relative thyroid weight was also significantly increased by iodine deficiency. Restricted feeding per se decreased thyroid weight by on average $33 \%$, but relative thyroid weight was unchanged. Restricted feeding did not alter the iodine:creatinine ratio in urine. The ratio was significantly lowered in iodine deficiency.

\section{Thyroid Hormones}

Restricted feed intake lowered $\mathrm{T}_{4}$ levels in plasma (Table 2). Reduced plasma $\mathrm{T}_{4}$ concentrations were also observed in the iodine-deficient rats. Rats fed restricted amounts of the control diet had significantly lower mean $T_{3}$ concentrations than their counterparts fed ad libitum. $T_{3}$ concentration was not affected by iodine deficiency.

\section{Iodothyronine Deiodinase Activities}

No differences between groups in protein concentration of liver and brain homogenates were found (Table 3 ). In rats fed ad libitum, specific activities of hepatic type I deiodinase and brain type II deiodinase were 
Table 1

Effects of lodine Deficiency and/or Food Restriction on Growth, Body Weight, and Organ Weights

\begin{tabular}{|c|c|c|c|c|c|c|}
\hline \multirow{3}{*}{$\begin{array}{l}\text { Feeding regimen: } \\
\text { Diet: }\end{array}$} & \multicolumn{4}{|c|}{ Restricted } & \multicolumn{2}{|c|}{ Ad libitum } \\
\hline & \multicolumn{2}{|c|}{ Control, $n=12$} & \multicolumn{2}{|c|}{ I deficient, $n=12$} & \multicolumn{2}{|c|}{ Control, $n=6$} \\
\hline & Mean & $\mathrm{SD}$ & Mean & SD & Mean & $\mathrm{SD}$ \\
\hline Growth, g/d & $2.3^{a}$ & 0.3 & 2.2 & 0.2 & 5.3 & 0.3 \\
\hline Body weight, g & $234.2^{a}$ & 8.8 & 229.0 & 10.3 & 364.0 & 9.0 \\
\hline Liver weight, $g$ & $6.01^{\prime \prime}$ & 0.56 & 5.81 & 0.57 & 14.28 & 1.09 \\
\hline Liver weight, & & & & & & \\
\hline $\mathrm{g} / 100 \mathrm{~g} \mathrm{BW}$ & $2.57^{\mu}$ & 0.24 & 2.53 & 0.20 & 3.92 & 0.27 \\
\hline $\begin{array}{l}\text { Brain weight, } g \\
\text { Brain weight. }\end{array}$ & $1.71^{h}$ & 0.04 & 1.67 & 0.08 & 1.80 & 0.07 \\
\hline $\begin{array}{c}\text { g/100 g BW } \\
\text { Weight kidneys, }\end{array}$ & $0.73^{a}$ & 0.02 & 0.73 & 0.05 & 0.50 & 0.03 \\
\hline Weight kidneys, & $1.57^{a}$ & 0.10 & 1.57 & 0.10 & 2.31 & 0.19 \\
\hline $\mathrm{g} / 100 \mathrm{~g} \mathrm{BW}$ & 0.67 & 0.05 & 0.68 & 0.04 & 0.63 & 0.05 \\
\hline $\begin{array}{l}\text { Spleen weight, g } \\
\text { Spleen weight, }\end{array}$ & $0.41^{\prime \prime}$ & 0.03 & 0.40 & 0.03 & 0.60 & 0.07 \\
\hline $\mathrm{g} / 100 \mathrm{~g} \mathrm{BW}$ & 0.17 & 0.01 & 0.17 & 0.02 & 0.17 & 0.02 \\
\hline $\begin{array}{l}\text { Pituitary weight, } \\
\text { mg }\end{array}$ & $7.1^{a}$ & 0.5 & 7.0 & 0.7 & 9.8 & 0.9 \\
\hline $\begin{array}{c}\text { Pituitary weight, } \\
\mathrm{mg} / 100 \mathrm{~g} \mathrm{BW}\end{array}$ & $3.0^{h}$ & 0.2 & 3.0 & 0.3 & 2.7 & 0.2 \\
\hline
\end{tabular}

"Restricted control vs ad libitum control diet, $p<0.001$.

${ }^{b}$ Restricted control vs ad libitum control diet, $p<0.025$.

similar to those in rats fed on a restricted basis. Type I deiodinase activity in whole liver had decreased by restricted feeding. Restricted feeding significantly lowered type III deiodinase activity in brain. Iodine deficiency did not affect the specific activity of type I deiodinase in liver, but increased group mean type II deiodinase activity in brain. The stimulatory effect of iodine deficiency on brain type II deiodinase activity did not reach statistical significance $(p=0.049)$. In a parallel experiment (unpublished), we used diets that were identical to those in the present study, but without selenium $\left(\mathrm{Na}_{2} \mathrm{SeO} \cdot 5 \mathrm{H}_{2} \mathrm{O}\right)$ added to the mineral premix. Selenium contents of the diets were determined using two different methods $(19,20)$. Analysis showed that the control diet of the present study contained 0.19 (19) or 0.15 (20) $\mathrm{mg} \mathrm{Se} / \mathrm{kg}$. The analyzed selenium concentrations of the diets used in the present and parallel study were as follows: iodine sufficient diet without added selenium, 0.09 (19) or 0.07 (20) $\mathrm{mg} \mathrm{Se} / \mathrm{kg}$; iodine deficient diet with added selenium, $0.10 \mathrm{mg} \mathrm{Se} / \mathrm{kg}$; iodine deficient diet without added selenium, $0.09 \mathrm{mg} \mathrm{Se} / \mathrm{kg}$. The latter two diets were analyzed using the method of Koh and Benson (19) only. 
Table 2

Effect of lodine Deficiency or Food Restriction on lodine Status

\begin{tabular}{|c|c|c|c|c|c|c|}
\hline \multirow{3}{*}{$\begin{array}{l}\text { Feeding regimen: } \\
\text { Diet: }\end{array}$} & \multicolumn{4}{|c|}{ Restricted } & \multicolumn{2}{|c|}{ Ad libitum } \\
\hline & \multicolumn{2}{|c|}{ Control, $n=12$} & \multicolumn{2}{|c|}{1 deficient, $n=12$} & \multicolumn{2}{|c|}{ Control, $n=6$} \\
\hline & Mean & SD & Mean & SD & Mean & $\mathrm{SD}$ \\
\hline $\begin{array}{l}\text { Urinary iodine, } \\
\mu \mathrm{g} / / \mathrm{d}\end{array}$ & 3.21 & 1.11 & $0.66^{\circ}$ & 0.20 & 3.90 & 0.97 \\
\hline $\begin{array}{l}\text { Urinary creatinine, } \\
\mathrm{mM}\end{array}$ & $6.79^{\prime \prime}$ & 2.52 & 6.79 & 3.31 & 12.03 & 2.97 \\
\hline $\begin{array}{l}\text { Urinary iodine, } \\
\mu g l / g \text { creatinine }\end{array}$ & 290.7 & 111.4 & $58.3^{\circ}$ & 17.5 & 230.6 & 70.9 \\
\hline $\begin{array}{l}\text { Thyroid weight, } \\
\text { mg } \\
\text { Thyroid weight. }\end{array}$ & $17.8^{a \prime}$ & 2.0 & $22.4^{6}$ & 3.9 & 26.5 & 5.8 \\
\hline $\begin{array}{l}\text { mg/100 g BW } \\
\text { Plasma } 1_{4}\end{array}$ & 7.6 & 0.9 & $9.8^{4}$ & 1.9 & 7.3 & 1.6 \\
\hline$n M$ & $63^{b}$ & 10 & 49 & 8 & 81 & 9 \\
\hline $\begin{array}{c}\text { Plasma } \mathrm{T}_{3} \\
\mathrm{nM}\end{array}$ & $0.35^{a}$ & 0.09 & 0.38 & 0.15 & 0.50 & 0.09 \\
\hline
\end{tabular}

"Restricted control vs ad libitum control diet, $p<0.001$.

'Restricted control vs ad libitum control diet, $p<0.025$.

'Restricted iodine deficient vs restricted control diet, $p<0.001$.

${ }^{4}$ Restricted iodine deficient vs restricted control diet, $p<0.025$.

Table 3

Effect of lodine Deficiency or Food Restriction on Deiodinase Activities

\begin{tabular}{|c|c|c|c|c|c|c|}
\hline \multirow{3}{*}{$\begin{array}{l}\text { Feeding regimen: } \\
\text { Diet: }\end{array}$} & \multicolumn{4}{|c|}{ Restricted } & \multicolumn{2}{|c|}{ Ad libitum } \\
\hline & \multicolumn{2}{|c|}{ Control, $n=12$} & \multicolumn{2}{|c|}{ I deficient, $n=12$} & \multicolumn{2}{|c|}{ Control, $n=6$} \\
\hline & Mean & $\overline{\mathrm{SD}}$ & Mean & $\overline{\mathrm{SD}}$ & $\overline{\text { Mean }}$ & $\overline{\mathrm{SD}}$ \\
\hline $\begin{array}{l}\text { Hepatic deiodinase- } \mathrm{I}, \\
\mathrm{pmol} / \mathrm{mg} / \mathrm{min}\end{array}$ & 264 & 51 & 252 & 42 & 296 & 82 \\
\hline $\begin{array}{l}\text { Brain deiodinase-II, } \\
\mathrm{fmol} / \mathrm{mg} / \mathrm{h}\end{array}$ & 4.74 & 1.02 & 6.00 & 1.82 & 3.98 & 0.90 \\
\hline $\begin{array}{l}\text { Brain deiodinase-III } \\
\mathrm{pmol} / \mathrm{mg} / \mathrm{h}\end{array}$ & $3.39^{4}$ & 0.50 & 3.43 & 0.32 & 4.82 & 0.69 \\
\hline $\begin{array}{l}\text { Protein content of } \\
\text { liver homogenates, } \\
\mathrm{mg} / \mathrm{mL} \\
\text { Protein content of } \\
\text { brain homogenates, } \\
\mathrm{mg} / \mathrm{mL}\end{array}$ & 16.5 & 1.1 & 16.3 & 0.9 & 14.7 & 2.1 \\
\hline
\end{tabular}

${ }^{\circ}$ Restricted control vs ad libitum control diet, $p<0.001$. 
The diets without added selenium used in the parallel study were also fed to rats at a level of $60 \%$ of ad libitum intake for a period of $42 \mathrm{~d}$. Iodine deficiency as induced with the diets without added selenium was found to significantly ( $p=0.001)$ increase brain type Il deiodinase activity, the activities in deficient and sufficient animals being $7.3 \pm 2.2$ and $4.6 \pm 0.8$ $\mathrm{fmol} / \mathrm{h}$ per mg protein (means $\pm \mathrm{SD}, n=12$ ). In that experiment type III deiodinase activity in brain homogenates was not affected by iodine deficiency.

\section{DISCUSSION}

At the end of the experiment, the control and iodine-deficient groups fed restricted amounts of feed had similar body and organ weights, except for the thyroid gland. As would be expected (4), iodine deficiency as only variable raised thyroid weight and lowered plasma $T_{4}$ concentrations. These results indicate that the iodine-deficient rats had a mild form of hypothyroidism, but growth rate was not affected.

The control groups fed either ad libitum or on a restricted basis had similar daily excretions of iodine. Thus, the control rats fed restricted amounts of feed can be considered iodine sufficient; their iodine intake was on average $0.015 \mu \mathrm{mol} / \mathrm{d}$. Iodine intake of the rats fed the control diet ad libitum was on average $0.025 \mu \mathrm{mol} / \mathrm{d}$. However, this difference in iodine intake owing to ad libitum vs restricted feeding, did not significantly affect daily iodine excretion. Furthermore, the decrease in daily iodine excretion owing to restricted feeding, was not proportional to the decrease in iodine intake. It can be hypothesized that iodine excretion in the form of $\mathrm{T}_{4}$ and its metabolites in feces is decreased, leading to a higher proportion of iodine in urine $(21,22)$.

Urinary iodine:creatinine ratios were determined to monitor the iodine status of the rats. After six weeks, the ratio was lowered by about $80 \%$ in the rats fed the diet without added iodine when compared with the controls who were fed on a restricted basis. Restricted feeding lowered urinary creatinine levels. A lowering effect of malnutrition on urinary creatinine concentration has also been reported for humans (23). Thus, the iodine:creatinine ratio as such may be an unreliable index to compare iodine status of undernourished people with that of wellnourished people. Twenty-four-hour-urinary iodine excretion is a better index of the iodine status in areas where malnutrition occurs.

lodine deficiency per se did not influence hepatic $T_{4}$ to $T_{3}$ monodeiodination as based on type I deiodinase activity. Possibly, type I monodeiodinase activity is decreased only when circulating thyroid hormones are markedly reduced. Evidence for this notion has been presented earlier $(7,8)$.

Iodine-deficient rats had an increased activity of type Il deiodinase in brain. The activity that we found is rather low when compared with 
other studies $(8,9)$. This can be explained by the fact that we used homogenates of brain tissue consisting of cerebral cortex, striatum, and midbrain. Unlike others $(9,10)$ we did not include cerebellum, which has a relatively high activity of type II deiodinase $(9,10)$. Moreover, we used homogenates instead of microsomes. Our results do show that a mild reduction in serum $T_{4}$ is associated with an increase in apparent type II deiodinase activity. Interference of type II deiodinase measurement by endogenous $T_{4}$ cannot be excluded. However, it is unlikely that a change in endogenous $T_{4}$ in the homogenates accounts for the observed increase in type II deiodinase activity in iodine-deficient rats. The $\mathrm{T}_{4}$ concentration in the incubation mixture (endogenous plus tracer) as estimated according to Van Doorn et al. (24) was far below the apparent $K_{m}(1 \mathrm{nM})$ of the type II deiodinase (7). Furthermore, the contribution of endogenous $T_{4}$ probably is low compared to the added tracer $T_{4}$. Thus, variations in brain $T_{4}$ concentrations may not have measurably affected deiodinase type II activity.

Marginal iodine deficiency did not affect brain type III deiodinase activity. Studies using thyroidectomized rats with severely reduced $\mathrm{T}_{4}$ levels have shown decreased type III deiodinase activities $(9,10)$.

Food restriction lowered plasma $T_{4}$ and $T_{3}$ concentrations. The decreased $T_{3}$ levels in plasma may limit energy expenditure during a period of restricted feed intake. Schröder-van der Elst and Van der Heide (21) described that restricted feeding of rats lowers peripheral $T_{3}$ production. The present results show that specific hepatic type I deiodinase was not reduced by food restriction. However, because of the decrease in liver weight, type I deiodinase activity in whole liver was decreased. The lowering effect of food restriction on $T_{3}$ to $T_{2}$ monodeiodination in brain can be considered as a mechanism, protecting the brain against shortage of $T_{3}$, even in situations when $T_{4}$ levels are decreased.

In sum, under the present experimental conditions marginal iodine deficiency had predictable effects on thyroid function. Food restriction alone also influenced thyroid hormone metabolism as evidenced by a fall of plasma $T_{4}$ and $T_{3}$ levels and a significant decrease in type III deiodinase activity in brain. In addition, in rats with mild hypothyroidism brain type II deiodinase activity was increased. Type II deiodinase in brain seems more sensitive to minor changes in plasma levels of $T_{4}$ than type I and III deiodinases. This can be seen as a compensatory mechanism to maintain a normal tissue $T_{3}$ concentration in spite of a fall in circulating $T_{4}$ level.

\section{REFERENCES}

1. B. S. Hetzel, (1987), The Prevention and Control of lodine Deficiency Disorders, United Nations Administrative Committee on Coordination, Subcommittee on Nutrition, State-of-the art series, Nutrition Policy Discussion Paper \#3, Elsevier, Amsterdam. 
2. J. B. Vanderpas, B. Contempré, N. L. Duale, W. Goossens, N. Bebe, R. Thorpe, K. Ntambue, J. E. Dumont, C. H. Thilly, and A. T. Diplock, Am. J. Clin. Nutr. 52, 1087-1093 (1990).

3. B. Contempré, J. B. Vanderpas, and J. E. Dumont, Molecular and Cellular Endocrinology 81, C193-195 (1991).

4. H. Fukuda, N. Yasuda, M. A. Greer, M. Kutas, and S. E. Greer, Endocrinology 97, 307-314 (1975).

5. M. J. Obregón, P. Santisteban, A. Rodiguez-Peña, A. Pascual, P. Cartagena, A. Ruiz-Macros, L. Lamas, F. Escobar del Rey, and G. Morreale de Escobar, Endocrinology 115, 614-624 (1984).

6. P. Santisteban, M. J. Obregón, A. Rodriguez-Peña, L. Lamas, F. Escobar del Rey, and G. Morreale de Escobar, Endocrinology 110, 1780-1789 (1982).

7. P. R. Larsen, lodine and the brain, G. R. DeLong, J. Robbins, and P. G. Condiffe, eds., Plenum Press, New York, pp. 5-18 (1988).

8. J. E. Silva and J. L. Leonard, Endocrinology 116, 1627-1635 (1985).

9. M. M. Kaplan, U. D. McCann, K. A. Yaskoski, P. R. Larsen, and J. L. Leonard, Endocrinology 109, 397-402 (1981).

10. M. M. Kaplan, and K. A. Yaskoski, J. Clin. Invest. 66, 551-562 (1980).

11. 1. M. Kolthoff and E. B. Sandell, Mikrochim. Acta 1, 9-17 (1937).

12. O. Folin, J. Biol. Chem. 17, 469-473 (1914).

13. P. R. Larsen, J. Clin. Invest. 51, 1939-1949 (1972).

14. C. van Hardeveld and A. A. H. Kassenaar, Acta Endocrinol. 83, 305-312 (1976).

15. J. A. Mol, R. Docter, G. Henneman, and T. J. Visser, Biochem. Biophys. Res. Comm. 120, 28-36 (1984).

16. M. Rutgers, I. G. A. J. Pigmans, F. Bonthuis, R. Docter, and T. J. Visser, Endocrinology 125, 2175-2186 (1989).

17. SPSS Inc. SPSS/PC + STATISTICS 4.0, McGraw-Hill, Chicago (1990).

18. G. W. Snedecor and W. G. Cochran, Statistical Methods, 7th ed., Iowa State University Press, Ames (1980).

19. T. Koh and T. H. Benson, J. Assoc. Off. Anal. Chem. 66, 918-926.

20. M. de Bruin, J. M. Korthoven, and P. Bode, J. Radioanul. Chem. 70, 497-512.

21. J. P. Schröder-van der Elst and D. van der Heide, Diabetes 41, 147-152 (1992).

22. I. P. Schröder-van der Elst and D. van der Heide, I. Endocrinol. Invest. 15 (Suppl. 2), 46 (1992).

23. P. Bourdoux, C. Thilly, F. Delange, and A. M. Ermans, Towards the Eratication of Endemic Goiter, Cretinism and lodine Deficiency. J. T. Dunn, E. A. Pretell, C. H. Daza, and F. E. Viteri, eds., Pan American Health Organization/ WHO, Washington, Scientific Publication \#502. pp. 115-129 (1986).

24. J. van Doorn, F. Roelfsema, and D. van der Heide, Endocrinology 117, $1201-$ 1208 (1985). 